\title{
IDENTIFICATION OF POLYMORPHISMS IN THE MYOSTATIN AND LEPTIN GENES OF SANTA INÊS BREED AND CROSSBREED SHEEP AND ASSOCIATION WITH CARCASS TRAITS
}

\author{
IDENTIFICAÇÃO DE POLIMORFISMO NOS GENES DA MIOSTATINA E LEPTINA \\ EM OVINOS SANTA INÊS E CRUZADOS E ASSOCIAÇÃO COM \\ CARACTERÍSTICAS DE CARCAÇA
}

\begin{abstract}
Celia Raquel QUIRINO ${ }^{1}$; Ricardo Lopes Dias da COSTA $^{2}$; Aline PACHECO ${ }^{3}$; Aparecida de Fátima MADELLA-OLIVEIRA ${ }^{4}$; Renato Travassos BELTRAME ${ }^{5}$; Amanda da Silva AZEVEDO ${ }^{1}$; Aylton BARTHOLAZZI JUNIOR ${ }^{1}$; Wilder Hernando Ortiz VEGA ${ }^{1}$

1. Laboratório de Reprodução e Melhoramento Genético Animal, CCTA, Universidade Estadual do Norte Fluminense Darcy Ribeiro-RJ, Brazil. CNPq fellowship. crq@uenf.br; 2. Instituto de Zootecnia, da Agência Paulista de Tecnologia dos Agronegócios, Nova Odessa, SP, Brasil; 3. Universidade Federal do Oeste do Pará - PA, Brasil; 4. Instituto Federal do Espírito Santo, Alegre, ES, Brazil; 5. Centro Universitário do Espírito Santo - UNESC; Colatina, ES. Brasil
\end{abstract}

\begin{abstract}
The objective of this study was to identify polymorphisms in the myostatin and leptin genes in Santa Inês (SI) and crossbreed (SI x Dorper) sheep, to verify the effect of these polymorphisms on carcass traits. We evaluated seventy sheep of 8-month-old at the Federal Institute of Espírito Santo, Brazil. Data collected were slaughter weight $(\mathrm{SW})$, hot carcass weight $(\mathrm{HCW})$, cold carcass weight $(\mathrm{CCW})$, loin weight, tenderloin weight and fat thickness (FT). The hot carcass yield (HCY) was calculated by the formula (HCW/SW) x 100. We collected hairs from each animal for DNA extraction by the alkaline protocol. The animals were genotyped for the G>A mutation in nucleotide 9827 of the myostatin gene and for three polymorphisms in exon 3 of the leptin gene, by the PCR-RFLP technique. The amplicons the myostatin and leptin gene were cleaved with restriction enzyme for allelic discrimination. The alleles were recorded for each animal and analysis of variance was performed to check the influence of the mutations on the carcass traits. The mutant allele of the myostatin gene showed association with increased measures of CCW, FT and with reduced HCY. Among the three alleles of the leptin gene, only one showed an effect (increased CCW). The other alleles were not associated with any traits.
\end{abstract}

KEYWORDS: Fat thickness. Mutation. Lamb. Myostatin. Leptin.

\section{INTRODUCTION}

The Santa Ines is the most popular local breed of Brazil characterized by high adaptive value, reproductive, resistance to gastrointestinal parasites in addition to a good weight development in the tropics (COSTA JÚNIOR et al., 2006). It has been used as maternal lineage at the crossing with specialized breeds in meat production by is adapted the climatic conditions in the tropics.

Some polymorphisms the myostatin gene, have been found to be associated with various livestock carcass traits (MIRHOSEINI; ZARE, 2012). This is possible because muscle growth is regulated by some members of the TGF- $\beta$ family, which myostatin stands out for having effects on the musculoskeletal system (BURKS; COHN, 2011).

The myostatin gene was discovered by McPherron et al. (1997) and was identified as a negative regulator gene for muscle production. In sheep, a polymorphism based on a guanine-toadenine transition in the 3'UTR of the myostatin gene was discovered. This mutation generates a
miRNA site that inhibits the gene's translation, so animals that carry this mutation can suffer from muscular hypertrophy (CLOP et al., 2006).

The leptin gene has also been shown to influence carcass traits. According to Nelson e Cox (2011), the presence of an allele from leptin restricts the ingestion of food by stimulating anorexigenic neurons to produce hormones that suppress appetite. Zhou et al. (2009) discovered four mutations in exon 3 of the leptin gene in sheep, generating five alleles, including the wild type allele. The study showed that of these four mutations, three altered the sequence of amino acids, and the authors suggested that these variations can have an impact on the function and activity of leptin.

The aim of this study was to identify the presence of the g.9827G $>$ A mutation in the myostatin gene responsible for double-muscled and to identify three mutations in exon 3 of the leptin gene by the PCR-RFLP technique in Santa Inês sheep, and to investigate the association of these mutations with quantitative carcass traits. 


\section{MATERIAL AND METHODS}

Was studied Santa Inês (38) and crossbreed Santa Inês x Dorper (32) sheep, reared at the Federal Institute of Espírito Santo - Alegre Campus, Brazil (latitude $20^{\circ} 45^{\prime} \mathrm{S}$, longitude $41^{\circ} 28^{\prime} \mathrm{W}$, altitude 120 $\mathrm{m})$. The DNA was extracted from the hairs roots collected from each animal. These bulbs were cut and placed in microtubes for the DNA extraction reaction by alkaline technique.

The amplification in PCR for the myostatin and leptin genes was carried out with a final volume of $20 \mu \mathrm{l}$ per reaction using specific primer of each gene (designed in Primer Express ${ }^{\circledR}$ Software 3.0) (Table 1). There was a negative control for each reaction.

Table 1. Information on the primers for the genes studied and their respective sequences.

\begin{tabular}{ccccc}
\hline Gene & Primer Sequence & Ta & Bp & Reference \\
\hline \multirow{2}{*}{ Myostatin } & $\begin{array}{r}\text { F 5'-TTATGGGTTCGTGATGGCTGT-3' } \\
\text { R 5' AGAGTTAAATCATTTTGGTTTGCTT-3, }\end{array}$ & \multirow{2}{*}{$57^{\circ} \mathrm{C}$} & $\begin{array}{c}129 \\
\text { bp }\end{array}$ & This Work \\
\hline \multirow{2}{*}{ Leptin } & $\begin{array}{c}\text { F 5'-AGGAAGCACCTCTACGCTC-3' } \\
\text { R 5'-CTTCAAGGCTTCAGCACC-3' }\end{array}$ & \multirow{2}{*}{$57^{\circ} \mathrm{C}$} & $\begin{array}{c}471 \\
\text { bp }\end{array}$ & $\begin{array}{c}\text { Zhou et al. } \\
\text { (2009) }\end{array}$ \\
\hline
\end{tabular}

Ta- temperature of annealing, Bp- size of

the amplified fragment in base pairs.

The PCR was performed with an Applied Veriti 96-well thermocycler with denaturing at 95 ${ }^{\circ} \mathrm{C}$ for 1 minute, followed by 40 amplification cycles, with denaturing at $95{ }^{\circ} \mathrm{C}$ for 30 seconds, annealing of the primers with temperature present in Table 1 for 1 minute and extension for 1 minute. After the last cycle, the reactions were submitted to a final step of 7 minutes at $72{ }^{\circ} \mathrm{C}$ for extension of the strands.

Aliquots of $3 \mu \mathrm{l}$ of the amplified samples were submitted to non-denaturing polyacrylamide gel electrophoresis at $8 \%$ with size of 20 centimeters. Together with the samples, $100 \mathrm{bp}$ DNA molecular weight markers (Promega) were applied for confirmation of the amplified fragments. The bands they were visualized in gel corresponding to the amplified DNA fragments in gel the bands corresponding to the amplified DNA fragments (129 bp for the myostatin gene fragment and $471 \mathrm{bp}$ for the leptin gene fragment).

The cleavage reactions by restriction enzyme were performed to identify the different alleles on the genes studied. On the myostatin gene a mutation was genotyped located in the 3'UTR, referred to as DQ530260:g.9827 G>A related to double muscling. The leptin gene acts as a regulator of energy balance. Three mutations were genotyped - allele EF534371 nucleotide 387 pb (G/T), allele EF534372 nucleotide $316 \mathrm{pb}$ (C/A) and allele EF534373 nucleotide $271 \mathrm{pb}(\mathrm{G} / \mathrm{A})$ - located on this gene's exon 3. The mutant nucleotide referenced as EF534374 (107C/T) was not genotyped because it is a synonym mutation.

The restriction enzymes were chosen by the NEBcutter V2.0 tool, in which part of the sequences where the mutations are located were analyzed. We chose the enzymes that recognized and cleaved the sequence when it did not present a mutant allele. Therefore, the cleaved samples are from animals not carrying the mutation, while the uncleaved samples are from animals carrying the mutation.

For the myostatin gene, we used the enzyme HpyCH4IV (New England BioLabs, Brazil). We choose a specific enzyme for each allele of the leptin gene. The enzyme AleI (New England BioLabs, Brazil) was chosen because it distinguishes the allele EF534371. Another enzyme used was aAciI (New England BioLabs, Brazil), recognizing individuals with a cytosine on the 316th nucleotide of exon 3 of the leptin gene, thus discriminating the allele EF534372. The allele EF534373 was genotyped using the enzyme MspI (New England BioLabs, Brazil).

All the cleavage reactions with restriction enzymes were carried out in a final volume of $20 \mu \mathrm{l}$, using $1 \mathrm{x}$ of a specific buffer for each restriction enzyme, $5 \mathrm{U}$ of the restriction enzyme in question, 4 $\mu 1$ of the PCR product and deionized water. There was a negative control for all the reactions. The samples were placed in the Applied Veriti 96-well thermocycler at $37^{\circ} \mathrm{C}$, the optimal temperature for the functioning of all the enzymes.

The products from the referred restriction enzymes were subjected to non-denaturing polyacrylamide gel electrophoresis at $8 \%$. The samples and a $100 \mathrm{bp}$ molecular weight marker (Promega DNA Ladder) were placed in the wells containing the gels for confirmation of the cleaved fragments. The gels were also photo-documented in a DNR MiniBIS Pro ${ }^{\circledR}$ bio-imaging system.

After the first analysis of the data, to confirm the results we repeated the cleavage reactions with the restriction enzymes for the 
individuals that presented mutations in the genes described.

The allele and genotype frequency were calculated. The data were analyzed by the GLM procedure of the SAS program (SAS, 2009), for the purpose of verifying the effect of each allele, both in the myostatin gene and leptin gene, on the traits of interest: live weight, hot carcass weight, cold carcass weight, carcass yield, and loin and tenderloin weight. The means were compared by the SNK test at $5 \%$.

\section{RESULTS}

The polymorphism genotyped in the 3'UTR of the myostatin gene, which is involved in $\mathrm{G}>\mathrm{A}$ exchange, was found in the population studied. Among the genotyped animals, 10 individuals were carriers of this mutation and the genotypes found were GG (homozygotes for absence of mutation) and GA (heterozygotes for the mutation). The AA genotype, corresponding to homozygotes for the mutation, was not found in any of the animals studied.

The frequency of allele A for this mutation was $7.69 \%$ and the frequency of allele $G$ was
$92.31 \%$. For the genotypes, the frequencies were $84.61 \% \mathrm{GG}, 15.38 \% \mathrm{GA}$ and $0 \% \mathrm{AA}$.

The animals of the Santa Inês breed in the present study did not present any mutation for the myostatin gene. Only the crossbreed animals were carriers of this mutation.

Our statistical analyses showed that some traits are influenced by allele A (mutant). The analysis of variance indicated that the heterozygote animals for the mutation had higher cold carcass weights. The mean for this trait among the heterozygote animals was $17.91 \mathrm{Kg}$ and was statistically different $(\mathrm{P}<0.05)$ from the homozygote individuals without the mutation, for which the average weight was $15.73 \mathrm{Kg}$ (Table 2).

Animals carrying the mutation also had greater fat thickness, with an average of $3.05 \mathrm{~mm}$, a figure statistically different $(\mathrm{P}<0.05)$ from that of the animals without this mutation, for which the average was $1.69 \mathrm{~mm}$ (Table 2).

The carcass yield trait also was statistically different for the heterozygote animals carrying the mutation. Nevertheless, the mean for this trait was lower in the individuals with polymorphism in the myostatin gene (Table 2).

Table 2. Means among the genotypes found in the myostatin gene for carcass traits.

\begin{tabular}{ccc}
\hline & \multicolumn{2}{c}{ Myostatin Genotypes } \\
\hline Traits & GG (Santa Inês) & GA (Crossbred) \\
SW (kg) & $34.49 \pm 5.47^{\mathrm{a}}$ & $37.65 \pm 5.15^{\mathrm{a}}$ \\
HCW (kg) & $18.17 \pm 3.42^{\mathrm{a}}$ & $17.85 \pm 3.10^{\mathrm{a}}$ \\
CCW (kg) & $15.73 \pm 3.09^{\mathrm{b}}$ & $17.91 \pm 2.98^{\mathrm{a}}$ \\
HCY (\%) & $53.65 \pm 8.97^{\mathrm{a}}$ & $47.26 \pm 2.68^{\mathrm{b}}$ \\
FT (mm) & $1.69 \pm 1.22^{\mathrm{b}}$ & $3.05 \pm 1.30^{\mathrm{a}}$ \\
Loin (kg) & $1.48 \pm 0.52^{\mathrm{a}}$ & $1.17 \pm 0.25^{\mathrm{a}}$ \\
Tenderloin (kg) & $0.14 \pm 0.04^{\mathrm{a}}$ & $0.14 \pm 0.04^{\mathrm{a}}$ \\
\hline
\end{tabular}

$\mathrm{SW}$ - slaughter weight, HCW- hot carcass weight, CCW- cold carcass weight, HCY- hot carcass yield, FT- fat thickness. Means followed by different letters in the row differ statistically $(\mathrm{P}<0.05)$ by the SNK test.

For allele EF534371, with fragments digested by the restriction enzyme AleI, the frequency of allele $\mathrm{T}$ was $24.60 \%$ and that of allele $\mathrm{G}$ was $75.40 \%$. The frequencies of the genotypes GG, GT and TT were $50.80 \%, 49.20 \%$ and $0 \%$, respectively.

There was no significant association $(\mathrm{P}>0.05)$ of this mutation with any of the carcass traits analyzed (Table 3).
The genotyping of the animals through the enzyme AciI for allele EF534372 identified only two heterozygote individuals for the mutation. The allele A frequency was $1.45 \%$ while that of allele $\mathrm{C}$ was $98.55 \%$. The frequencies of genotypes CA and CC were $2.9 \%$ and $97.1 \%$, respectively, while genotype AA was not found. 
Table 3. Means among the genotypes found in the leptin gene in alleles EF534371, EF534372 and EF534373 for the carcass traits.

\begin{tabular}{ccccccc}
\hline & \multicolumn{2}{c}{ Leptin EF534371 } & \multicolumn{2}{c}{ Leptin EF534372 } & \multicolumn{2}{c}{ Leptin EF534373 } \\
\hline Traits & $\begin{array}{c}\text { GG } \\
(\text { Santa Inês) }\end{array}$ & $\begin{array}{c}\text { GT } \\
(\text { Crossbred) }\end{array}$ & $\begin{array}{c}\text { CC } \\
(\text { Santa Inês })\end{array}$ & $\begin{array}{c}\text { CA } \\
(\text { Crossbred) }\end{array}$ & $\begin{array}{c}\text { GG } \\
(\text { Santa Inês })\end{array}$ & $\begin{array}{c}\text { GA } \\
(\text { Crossbred) }\end{array}$ \\
\hline SW (kg) & $34.23 \pm 5.87^{\mathrm{a}}$ & $35.74 \pm 5.15^{\mathrm{a}}$ & $34.78 \pm 5.38^{\mathrm{a}}$ & $42.25 \pm 5.30^{\mathrm{a}}$ & $34.99 \pm 5.48^{\mathrm{a}}$ & $36.00 \pm 7.05^{\mathrm{a}}$ \\
HCW (kg) & $17.43 \pm 2.81^{\mathrm{a}}$ & $18.81 \pm 3.72^{\mathrm{a}}$ & $17.96 \pm 3.29^{\mathrm{a}}$ & $21.50 \pm 2.83^{\mathrm{a}}$ & $18.06 \pm 3.36^{\mathrm{a}}$ & $19.25 \pm 3.18^{\mathrm{a}}$ \\
$\mathbf{C C W}(\mathbf{k g})$ & $15.87 \pm 3.21^{\mathrm{a}}$ & $16.50 \pm 3.16^{\mathrm{a}}$ & $15.96 \pm 3.02^{\mathrm{b}}$ & $21.30 \pm 2.83^{\mathrm{a}}$ & $16.04 \pm 3.14^{\mathrm{a}}$ & $19.35 \pm 2.47^{\mathrm{a}}$ \\
HCY (\%) & $51.62 \pm 8.16^{\mathrm{a}}$ & $53.10 \pm 8.90^{\mathrm{a}}$ & $52.41 \pm 8.65^{\mathrm{a}}$ & $50.87 \pm 0.31^{\mathrm{a}}$ & $52.52 \pm 8.60^{\mathrm{a}}$ & $48.27 \pm 3.28^{\mathrm{a}}$ \\
FT (mm) & $2.02 \pm 1.46^{\mathrm{a}}$ & $1.92 \pm 1.25^{\mathrm{a}}$ & $1.91 \pm 1.33^{\mathrm{a}}$ & $3.50 \pm 0.71^{\mathrm{a}}$ & $1.93 \pm 1.34^{\mathrm{a}}$ & $3.00 \pm 1.41^{\mathrm{a}}$ \\
$\begin{array}{c}\text { Loin (kg) } \\
\text { Tenderloin } \\
(\mathbf{k g})\end{array}$ & $1.31 \pm 0.39^{\mathrm{a}}$ & $1.53 \pm 0.57^{\mathrm{a}}$ & $1.43 \pm 0.50^{\mathrm{a}}$ & $1.14 \pm 0.13^{\mathrm{a}}$ & $1.42 \pm 0.50^{\mathrm{a}}$ & $1.31 \pm 0.30^{\mathrm{a}}$ \\
\hline
\end{tabular}

SW- slaughter weight, HCW- hot carcass weight, CCW- cold carcass weight, HCY- hot carcass yield, FT- fat thickness. Means followed by different letters in the row differ statistically $(\mathrm{P}<0.05)$ by the SNK test.

Of the traits evaluated, only cold carcass weight showed a significant difference $(\mathrm{P}<0.05)$ between the genotypes. Animals with genotype CA presented mean cold carcass weight of $21.30 \mathrm{~kg}$ while the average of $\mathrm{CC}$ animals was $15.96 \mathrm{~kg}$. There were no significant differences between the two genotypes found for the other traits (Table 3).

Allele EF534373, discriminated by the enzyme MspI, was only found in two animals. The frequency of the mutant allele A was $1.43 \%$ and of allele $\mathrm{G}$ was $98.57 \%$. The genotype frequencies were $2.86 \%$ for GA and $97.14 \%$ for GG.

Just as for allele EF534373, none of the carcass traits evaluated showed any effect of this polymorphism in the leptin gene (Table 3 ).

\section{DISCUSSION}

Comparison of the genotypes demonstrated the association of myostatin and leptin gene with carcass characteristics.

Hadjipavlou et al. (2008) found that Suffolk rams were not carriers of mutation in the myostatin gene, unlike Texel rams, which presented the mutant allele with frequency of nearly $100 \%$. However, Charollais sires presented a frequency of approximately $70 \%$ for the non-mutant allele and about $30 \%$ for the mutant allele.

Novianti et al. (2009) identified some QTLs that are related to carcass traits in cattle. The authors concluded that other genes exist that affect carcass traits, but some of them can undergo an epistatic effect with myostatin or interaction with this gene.

The two studies mentioned above clarify that the final trait expressed depends not only on the presence or absence of the mutation, because other biological factors can influence the final characteristic. There is evidence in the literature that can serve to explain why double musculature in sheep was not observed in the other traits in the present study.

Han et al. (2010) analyzed New Zealand Romney sheep for the presence of the mutation discovered by Clop et al. (2006) in the myostatin gene, by applying the PCR-SSCP technique. They only found individuals with genotypes GG and GA for this gene, the same genotypes found in our study. Those authors also investigated the effect of this mutation on some carcass traits and found higher means, with a significant effect $(\mathrm{p}<0.05)$, for the traits birth weight, loin yield, and total muscle yield in the heterozygote animals.

Hadjipavlou et al. (2008) did not find an association between genotype and live weight. Those authors, studying Charollais sheep, stated that the effect of allele A on the muscle depth appears to be partially recessive. This can explain the absence of an effect of the mutant allele on some of the carcass traits we studied, for which we only observed heterozygote individuals having the mutation and absence of homozygote individuals for allele A.

We also identified two more fragments, besides those corresponding to cleavage in the absence of mutation. These fragments appeared in some of the genotyped individuals. Since the sequence that was amplified contains only one cleavage site for the restriction enzyme, the presence of these fragments indicates that other polymorphisms can also be present in this amplicon. 
However, a more detailed analysis is necessary to confirm this hypothesis.

The genotypes found for all the polymorphisms in the leptin gene were homozygotes without mutation or heterozygotes. As in the case of the myostatin gene, homozygote individuals for the mutations were not found in the population studied.

Few studies have analyzed the effect of these alleles (EF534373 and EF534372) in sheep. Shojaei et al. (2010), applying the PCR-SSCP technique, characterized variations in exon 3 of the leptin gene in sheep bred in Iran. Different genotypes were found and their associations with the animals' traits were analyzed. The genotypes found by those authors affected the body weight at three, six and nine months of age.

Hajihosseinlo et al. (2012) also investigated the effect allele variance in exon 3 of the leptin gene on the growth traits of sheep in Iran. They used the same primer described by Zhou et al. (2009) to amplify a 471 base pair fragment referring to exon 3 of the leptin gene and applied the PCR-SSCP technique for allele discrimination of the individuals. They found different alleles and genotypes, some of which significantly improved some growth traits, such as weaning weight, sixmonth and nine-month weight and yearling weight. One genotype was associated with greater birth weight than the others found.

Barzehkar et al. (2009) analyzed the effect of leptin gene polymorphisms in three sheep breeds in Iran. Besides evaluating the association of these polymorphisms with growth traits, as in the other studies mentioned, they also analyzed other carcass characteristics. However, the primer they used covered exon 2 and part of intron 2 and the allele discrimination was carried out through SSCP and sequencing. The authors found distinct alleles and genotypes within this amplicon, along with a significant association of some polymorphisms with cold carcass weight, as shown by our study for allele EF534372. Significant associations were also found with total body fat weight, lean meat weight and fattail percent.

Finally, Boucher et al. (2006), in genotyping Dorset and Suffolk sheep by sequencing DNA fragments that included exon 2, intron 3 and the 3'UTR of the leptin gene, found two polymorphisms in intron 2 and one polymorphism in the 3'UTR. One of these alleles was associated with reduced muscle thickness and loin eye area of the Suffolk breed.

It can be concluded that the polymorphic allele of the myostatin gene showed a significant association with increased hot carcass weight and fat thickness but with decreased carcass yield.

Among the polymorphisms of the leptin gene studied, only EF534372 showed an association with a carcass trait (increased cold carcass weight).

Certain alleles in the myostatin and leptin genes have positive effects on carcass traits. However, for these alleles to be used as a tool for genetic improvement of meat sheep, further investigation is necessary of the association of polymorphisms in the myostatin and leptin genes with carcass traits and the possibility of negative effects on animal performance.

\section{ACKNOWLEDGEMENTS}

We are grateful for the financial support of the CnPQ, CAPES and FAPERJ Research Foundations.

RESUMO: O objetivo deste estudo foi identificar os polimorfismos nos genes da miostatina e leptina em Santa Inês (SI) e mestiças (SI x Dorper) ovelhas, para verificar o efeito desses polimorfismos sobre características de carcaça. Foram avaliadas setenta ovelhas com oito meses de idade, do Instituto Federal do Espírito Santo, Brasil. Os dados coletados foram o peso de abate (PA), peso de carcaça quente (PCQ), peso de carcaça fria (PCF), peso de lombo, peso lombinho e espessura de gordura de cobertura (ECG). O rendimento de carcaça quente (RCQ) foi calculado pela fórmula (PCQ/PA) x 100. Foram coletados pelos de cada animal para a extração de DNA pelo protocolo alcalino. Os animais foram genotipados para a mutação $\mathrm{G}>\mathrm{A}$ no nucleotídeo 9827 do gene da miostatina e para três polimorfismos no exon 3 do gene da leptina, através da técnica PCR-RFLP. Os produtos de amplificação do gene da miostatina e da leptina foram clivados com a enzima de restrição para diferenciação alélica. Os alelos encontrados foram registrados para cada indivíduo e então foi realizada a análise de variância para verificar os efeitos das mutações sobre as características de carcaça pelo procedimento GLM do SAS. O alelo mutante do gene da miostatina mostrou associação com o aumento das médias PCF e ECG e com a redução do RCQ. Entre os três alelos do gene da leptina, apenas um apresentou efeito com aumento do PCF. Os demais alelos e as demais características não apresentaram associação.

PALAVRAS-CHAVE: Espessura de gordura. Mutação. Cordeiro. Miostatina. Leptina. 


\section{REFERENCES}

BARZEHKAR, R., SALEHI, A., MAHJOUBI, F. Polymorphisms of the ovine leptin gene and its association with growth and carcass traits in three Iranian sheep breeds. Iranian Journal of Biotechnology, v. 7, p. 241246. 2009.

BOUCHER, D., SWLIN, M. F., CASTONGUAY, F., GARIÉPY, C., POTHIER, F. Detection of polymorphisms in the ovine leptin $(L E P)$ gene: Association of a single nucleotide polymorphism with muscle growth and meat quality traits. Canadian Journal Of Animal Science, v. 86, p. 31-35. 2006.

BURKS, T. N., COHN, R. D. Role of TGF-b signaling in inherited and acquired Myopathies. Skeletal Muscle, v. 1, n. 19, p. 1-13. 2011. http://dx.doi.org/10.1186/2044-5040-1-19

CLOP, A., MAHCY, F., TAKEDA, H., PIROTTIN, D., TORDOIR, X., BIBÉ, B., BOUIX, J., CAIMENT, F., ELSEN, J.-M., EYCHENNE, F., LARZUL, C., LAVILLE, E., MEISH, F., MILENKOVIC, D., TOBIN, J., CHARLIER, C., GEORGES, M. A. Mutation creating a potential illegitimate microRNA target site in the myostatin gene affects muscularity in sheep. Nature Genetics, v. 38, p. 813-818. 2006.

http://dx.doi.org/10.1038/ng1810

COSTA JÚNIOR, W. H., CAMPELO, J. E. G., AZEVÊDO, D. M. M. R., MARTINS FILHO, R., CAVALCANTE, R. R., LOPES, J. B., OLIVEIRA, M. E. Caracterização morfométrica de ovinos da raça Santa Inês criados nas microrregiões de Teresina e Campo Maior, Piauí. Revista Brasileira de Zootecnia, v. 35, p. 2260-2267. 2006. http://dx.doi.org/10.1590/S1516-35982006000800009

HADJIPAVLOU, G., MATIKA, O., CLOP, A., BISHOP, S. C. Two single nucleotide polymorphisms in the myostatin (GDF8) gene have significant association with muscle depth of commercial Charollais sheep.

Animal Genetics, v. 39, p. 346-353. 2008. http://dx.doi.org/10.1111/j.1365-2052.2008.01734.x

HAJIHOSSEINLO, A., HASHEMI, A., SADEGHI, S. Association between polymorphism in exon 3 of leptin gene and growth traits in the Makooei sheep of Iran. Livestock Research for Rural Development, v. 24, p. 9. 2012.

HAN, J., ZHOU, H., FORREST, R. H., SEDCOLE, J. R., FRAMPTON, C. M., HICKFORD, J. G. H. Effect of myostatin (MSTN) g+6223G $>$ A on production and carcass traits in New Zealand Romney sheep. Asian-

Australian Journal of Animal Science, v. 23, p. 863-866. 2010. http://dx.doi.org/10.5713/ajas.2010.90392

MCPHERRON, A. C., LAWLER, A. M., LEE, S.-J. Regulation of skeletal muscle mass in mice by a new TGF- $\beta$ superfamily member. Nature, v. 387, p. 83-90. 1997. http://dx.doi.org/10.1038/387083a0

MIRHOSEINI, S. Z., ZARE, J. The Role of Myostatin on Growth and Carcass Traits and its Application in Animal Breeding. Life Science Journal, v. 9, p. 2353-2357. 2012.

NELSON, D. L., COX, M. M. (2011). Princípios De Bioquímica de Lehninger. 5th ed. Artmed Editora. p. 930933.

NOVIANTI, I., PITCHFORD, W. S., BOTTEMA, C. D. K. Mapping of quantitative trait loci (QTL) for muscularity in beef cattle. Animal Breeding and Genetics, v. 18, p. 628-631. 2009.

SAS Institute Inc. SAS/STAT® 9.2 User’s Guide. Cary, SAS Institute Inc., 2009.

SHOJAEI, M., ABADI, M. M, FOZI, M. A., DAYANI, O., KHEZRI, A., AKHONDI, M. Association of growth trait and Leptin gene polymorphism in Kermani sheep. Journal of Cell and Molecular Research, v. 2, p. 67-73. 2010.

ZHOU, H., HICKFORD, J. G. H., GONG, H. Identification of allelic polymorphism in the ovine leptin gene. Molecular Biotechnology, v. 41, p. 22-25. 2009. http://dx.doi.org/10.1007/s12033-008-9090-3 